\title{
Supplemental chromium in cold-stressed buffalo calves (Bubalus bubalis): effects on growth performance, nutrient utilization and cell mediated and humoral immune response
}

\author{
Muneendra Kumar ${ }^{1 *}$, Harjit Kaur ${ }^{2}$, Veena Mani ${ }^{3}$, Rijusmita S. Deka ${ }^{4}$, \\ Amrish K. Tyagi ${ }^{3}$, Gulab Chandra ${ }^{5}$, Ajay K. Dang ${ }^{6}$, and Raju Kushwaha ${ }^{1}$ \\ ${ }^{I}$ Department of Animal Nutrition, College of Veterinary Science and Animal Husbandry, DUVASU, \\ Mathura, India \\ ${ }^{2}$ Agricultural Extension Division, Indian Council of Agricultural Research, Pusa, New Delhi, India \\ ${ }^{3}$ Dairy Cattle Nutrition Division, National Dairy Research Institute, Karnal, India \\ ${ }^{4}$ Krishi Vigyan Kendra, Dhemaji, India \\ ${ }^{5}$ Department of Veterinary Physiology and Biochemistry, Sardar Vallabhbhai Patel University of Agriculture \\ and Technology, Meerut, India \\ ${ }^{6}$ Dairy Cattle Physiology, National Dairy Research Institute, Karnal, India
}

KUMAR, M., H. KAUR, V. MANI, R. S. DEKA, A. K. TYAGI, G. CHANDRA, A. K. DANG, R. KUSHWAHA: Supplemental chromium in cold-stressed buffalo calves (Bubalus bubalis): effects on growth performance, nutrient utilization and cell mediated and humoral immune response. Vet. arhiv 87, 441-456, 2017.

\section{ABSTRACT}

Various stressors significantly increase urinary excretion of chromium $(\mathrm{Cr})$, suggesting that $\mathrm{Cr}$ may be physiologically linked to the responses to control stress. The aim of this study was to determine the physiological responses of buffalo calves to increased $\mathrm{Cr}$ supply under low ambient temperature. In a randomized complete block design, twenty-four Murrah buffalo calves were assigned to 4 treatments for a period of 120 days. Treatments included either no supplemental $\mathrm{Cr}$ (control), $0.5 \mathrm{mg}$ of supplemental $\mathrm{Cr} / \mathrm{kg}$ $\mathrm{DM}, 1.0 \mathrm{mg}$ of supplemental $\mathrm{Cr} / \mathrm{kg} \mathrm{DM}$, or $1.5 \mathrm{mg}$ of supplemental $\mathrm{Cr} / \mathrm{kg} \mathrm{DM}$. Buffalo calves were monitored daily for physiological variables, dry matter intake (DMI) and fortnightly for body mass change. Blood samples were collected at fortnightly intervals and analyzed for the biomarkers of immunity and plasma trace mineral concentration. At the end of the 120 day experimental period, a 7 day metabolic trial was conducted. The average temperature-humidity index (THI) and relative humidity (RH) during the study were 58.10 units and $52.0 \%$ respectively. Physiological variables, DMI and growth performance did not differ among all treatments. $1.5 \mathrm{mg} \mathrm{Cr} / \mathrm{kg} \mathrm{DM}$ increased B and T-cell proliferation, neutrophil phagocytic activity and ferric reducing antioxidant power (FRAP) value, whereas plasma total immunoglobulin (TIg) and immunoglobulin G (IgG)

\footnotetext{
*Corresponding author:

Muneendra Kumar, Assist. Prof., Department of Animal Nutrition, College of Veterinary Science and Animal Husbandry, DUVASU, Mathura 281001, India, Mobile number: +91904554 6435; E-mail address: muneendra82@gmail.com
} 
M. Kumar et al.: Effect of chromium supplementation on performance of cold-stressed buffalo calves

concentrations were the highest in the 1.0 and $1.5 \mathrm{mg} \mathrm{Cr} / \mathrm{kg} \mathrm{DM}$ group. Nutrient digestibility, nitrogen (N) metabolism and trace mineral bioavailability did not differ between treatments, while the bioavailability of $\mathrm{Cr}$ showed a positive correlation with supplemental $\mathrm{Cr}$ level. The results suggest that in cold conditions, increased Cr supply can improve immune response without affecting physiological response, growth performance and nutrient utilization in buffalo calves.

Key words: buffalo calves, chromium, growth performance, immunity, cold-stressed

\section{Introduction}

Successful livestock production requires applying strategies that optimize the use of the environment and available nutrient sources in order to capitalize on the livestock's production potential. Changes in environmental temperature below and above the thermal comfort zone reduce animal performance (BLAHOVA et al., 2007). The best milk breeds of buffaloes are essentially of the riverine type, and are mostly confined to the northern part of India (MARAI and HAEEB, 2010). The cold climate in the northern region of the country is quite harsh and stressful because of the low ambient temperature and it is responsible for great economic losses due to the reduced performance of buffaloes (SINGH et al., 2014). Exposure of buffaloes to low ambient temperatures evokes a series of drastic changes in biological functions that include alteration in feed intake, efficiency and utilization, disturbances in metabolism of water, protein, energy and mineral balances and blood metabolites (MARAI and HAEEB, 2010). Cold stress also suppresses nonspecific immunity, alters antibody titer and modulates cell mediated immunity (MATSUMOTO and HUANG, 2000). It is, therefore essential to protect the buffaloes from cold stress to obtain optimum performance as per their genetic potential.

To minimize the adverse effect of environmental stress, various supplements and additives are used in dairy animal rations. Among these, $\mathrm{Cr}$ supplementation is one. The primary role of $\mathrm{Cr}$ in the metabolism is to potentiate the action of insulin through its presence in an organometallic molecule, the glucose tolerance factor (GTF) (SAHIN et al., 2002a). In domestic animals, $\mathrm{Cr}$ has been recognized as a new essential trace mineral and it has been suggested to alleviate stress associated effects (NRC, 1997). Supplemental Cr improves immune function by enhancing serum immunoglobulin production, antibody titer to antigens, or by reducing serum cortisol concentration and modulating inflammatory response (WEISS and SPEARS, 2005). There is evidence in humans and laboratory animals that various stressors significantly increase urinary excretion of $\mathrm{Cr}$, suggesting that $\mathrm{Cr}$ may be physiologically linked to the responses to or control of stress (BUNTING et al., 2000). Due to increased urinary losses of $\mathrm{Cr}$ during environmental stress, $\mathrm{Cr}$ needs to be supplemented during cold stress. Dietary supplementations of $\mathrm{Cr}$ alleviated the detrimental effects of heat stress (SAHIN et al., 2005) and cold stress (SAHIN et al., 2002a) in poultry studies. 
To the best of our knowledge, there have been no experimental studies regarding the effects of $\mathrm{Cr}$ supplementation on performance, nutrient utilization and immune response in cold-stressed dairy animals. Hence, the present study was designed to investigate the possible effects of $\mathrm{Cr}$ supplementation growth performance, nutrient digestibility, mineral bioavailability and immune response on buffalo calves during the cold season.

\section{Materials and methods}

The research was approved by the Institutional Animal Ethics Committee (IAEC), constituted as per Article number 13 of the Committee for the Purpose of Control and Supervision of Experiments on Animals (CPCSEA).

Experimental design, calves and treatments. Twenty-four Murrah buffalo calves (Bubalus bubalis) were divided randomly into four groups of six calves each. The buffalo calves were individually weighed and blocked according to body mass (174 $\pm 4 \mathrm{~kg})$ and age (10-13 months) before being assigned to treatments of: 1) a nutritionally adequate diet with no supplemental $\mathrm{Cr}$ (control), 2) control diet with $0.5 \mathrm{mg}$ of supplemental $\mathrm{Cr} /$ $\mathrm{kg} \mathrm{DM}, 3$ ) control diet with $1.0 \mathrm{mg}$ of supplemental $\mathrm{Cr} / \mathrm{kg} \mathrm{DM}$, or control diet with 1.5 $\mathrm{mg}$ of supplemental $\mathrm{Cr} / \mathrm{kg} \mathrm{DM}$ as $\mathrm{CrCl}_{3} \cdot 6 \mathrm{H}_{2} \mathrm{O}$ (Loba Chemie Pvt. Ltd.). To ensure that each buffalo calf consumed the calculated amount of $\mathrm{Cr}$, the $\mathrm{CrCl}_{3}$ was mixed with $50 \mathrm{~g}$ concentrate mixture, and scattered onto a small amount of green fodder before offering the diet. The treatment period continued for 120 days during the cold season. The calves were fed twice daily at $10.00 \mathrm{~h}$ and $18.00 \mathrm{~h}$ and their nutrient requirements were met by feeding concentrate mixture, berseem fodder and wheat straw (KEARL, 1982). The buffalo calves were individually tied with rope in separate well-ventilated concrete floor pens. Deworming of all the buffalo calves was undertaken before the start of the experiment. To study the effect of $\mathrm{Cr}$ supplementation on nutrient digestibility, $\mathrm{N}$ balance and mineral metabolism, a metabolic trial with a 4 day adaptation period followed by a 7 day collection period was conducted at the end of the study.

Chemical analyses. Samples of the feed offered, ort left and feces were analyzed for DM (ID no. 973.18c), crude protein (ID no. 4.2.08), ether extract (ID no. 920.85) and ash (ID no. 923.03) content, as per the procedure described by AOAC (1995). Acid detergent fiber (ADF) and neutral detergent fiber (NDF) were determined by the methods of VAN SOEST et al. (1991). Concentrations of Cr (HALDAR et al., 2009), Cu, Zn and Fe in feed, refuse left, feces, and urine were estimated using an atomic absorption spectrophotometer (Model Z-5000, Polarized Zeeman Atomic Absorption Spectrophotometer, Hitachi HighTechnologies Corporation, Tokyo, Japan). The composition of the basal diet fed during the experimental period is presented in Table 1. 
M. Kumar et al.: Effect of chromium supplementation on performance of cold-stressed buffalo calves

Table 1. Ingredients and chemical compositions of experimental diet

\begin{tabular}{|c|c|}
\hline Composition & Basal diet \\
\hline \multicolumn{2}{|c|}{ Ingredients ( $\%$ of DM) } \\
\hline Berseem fodder & 19.8 \\
\hline Wheat straw & 20.2 \\
\hline Ground yellow maize & 23.0 \\
\hline Groundnut cake & 15.7 \\
\hline De-oiled mustard cake & 5.3 \\
\hline Wheat bran & 6.4 \\
\hline Rice bran & 8.3 \\
\hline Salt & 0.3 \\
\hline Trace minerals and vitamins premix ${ }^{\mathrm{a}}$ & 1.0 \\
\hline $\mathrm{CrCl}_{3} \cdot 6 \mathrm{H}_{2} \mathrm{O}$ & Variable $^{\mathrm{b}}$ \\
\hline \multicolumn{2}{|c|}{ Chemical composition (g/kg DM) } \\
\hline Dry matter & 764 \\
\hline Organic matter & 902 \\
\hline Crude protein & 178 \\
\hline Neutral detergent fibre & 394 \\
\hline Acid detergent fibre & 263 \\
\hline Ash & 98 \\
\hline Chromium (mg/kg DM) & 0.20 \\
\hline Copper (mg/kg DM) & 22.81 \\
\hline Zinc (mg/kg DM) & 46.61 \\
\hline Iron (mg/kg DM) & 298.12 \\
\hline
\end{tabular}

aPremix composition per kilogram: vitamin A, 500,000 IU; vitamin D3, 10,000 IU; vitamin E, $100 \mathrm{mg}$; Ca, 190,000; P, 90,000; Na, 50,000; Cu, 300 mg; Fe, 3,000 mg; Mn, 2,000 mg; I, 100 mg; Co, 100 mg; Se, 1 mg;Mg, $19,000 \mathrm{mg}$; BHT antioxidant, $3,000 \mathrm{mg}$. ${ }^{\mathrm{b}}$ Supplemental $\mathrm{Cr}$ diets $(0.5,1.0$ and $1.5 \mathrm{ppm} \mathrm{Cr})$ were obtained by supplementing $\mathrm{Cr}$ with $0.5,1.0$ and $1.5 \mathrm{mg} / \mathrm{kg}$ DM in basal diet.

Biochemical procedures. Blood samples were withdrawn in heparinized vacuutainer tubes (Becton Drive, Franklin Lakes, NJ, USA) by jugular venipuncture on days 0, 15, $30,45,60,75,90,105$ and 120 post-Cr supplementation. Collected samples of blood were analyzed for B and T- cell proliferation, neutrophil phagocytic activity, plasma TIg, IgG, ferric reducing antioxidant power(FRAP) assay and plasma $\mathrm{Cr}, \mathrm{Cu}, \mathrm{Zn}$ and Fe concentration. The colorimetric MTT [3-(4, 5-dimethylthiazol-2-yl)-2, 5-diphenyltetrazolium bromide] assay described by MOSMANN (1983) was used to determined lymphocyte proliferation. The mitogens chosen to stimulate $\mathrm{T}$ and B-cells were concanavalin A (Con A) and lipopolysaccharide (LPS) respectively. Neutrophil phagocytic activity was determined by semi-quantitative microscopic nitroblue tetrazolium (NBT, Sigma-Aldrich, St Louis, 
MO, USA) assay as described by CHAI et al. (2005). TIg and IgG in the plasma samples were estimated by the Zn turbidity method (McEVAN and FISHER, 1970) and a "Bovine IgG ELISA kit" (Cusabio Biotech Co., Ltd. China) respectively. Total antioxidant activity was measured by FRAP stoichimetric assay (BENZIE and STRAIN, 1999). Plasma content of $\mathrm{Cr}, \mathrm{Cu}, \mathrm{Zn}$ and $\mathrm{Fe}$ were estimated using an atomic absorption spectrophotometer (Model Z-5000, Polarized Zeeman Atomic Absorption Spectrophotometer, Hitachi HighTechnologies Corporation, Tokyo, Japan). The buffalo calves were monitored daily for physiological variables, dry matter intake (DMI) and fortnightly for body mass change.

Climatic data and physiological response. Dry bulb temperature (Cdb) and wet bulb temperature (Cwb) (Zeal, UK) were recorded in degrees Celsius at 07.30h and 14.30h every day to calculate the temperature humidity index (THI) according to the following formula (McDOWELL et al., 1976):

\section{$\mathrm{THI}=0.72(\mathrm{Cdb}+\mathrm{Cwb})+40.6$}

Daily relative humidity $(\mathrm{RH})$ data were obtained by the difference between $\mathrm{Cdb}$ and Cwb. The physiological response of the experimental buffalo calves was determined daily by recording respiration rate (RR), pulse rate (PR) and rectal temperature (RT).

Statistical analyses. The data were subjected to the multivariate analysis of general linear model (GLM) procedure of the Statistical Software Package (SPSS for Windows, V19.0; SPSS Inc., Chicago, IL, USA). To estimate the effect of treatment and time period, and their interaction, the following model was used:

$$
Y i j k=\mu+T i+D j+(T \times D) i j+e i j k
$$

Where: Yijk is the dependent variable, $\mu$ the overall mean of the population, $T i$ the mean effect of the $i t h$ treatments, $D j$ the mean effect of the day of sampling with day as a repeated factor $(j=0,15,30,45,60,75,90,105$, and 120 days of dietary treatment), $(T \times D) i j$ the effect of the interaction between the effects of treatment, group and day of sampling, and eijk the unexplained residual element assumed to be independent and normally distributed. An individual animal was used as the experimental unit for all data. The pair-wise comparison of means was carried out using “Tukey's honest significant difference (HSD) test". Significance was determined at $\mathrm{P}<0.05$ and the values are presented in the tables.

\section{Results}

Climatic and physiological variable. The average THI during the experimental period of 120 days decreased with the decrease in environmental temperature and was lowest during the month of January (Fig. 1). In contrast to THI, RH \% was found to be highest during the month of January. The calculated THI and RH \% averaged 58.10 units and $52.00 \%$, respectively. Supplementation of different levels of inorganic $\mathrm{Cr}$ in the diet 
M. Kumar et al.: Effect of chromium supplementation on performance of cold-stressed buffalo calves

of cold-stressed buffalo calves did not show any significant effect on RR, PR and RT (Table 2).

Table 2. Effect of Cr supplementation on growth performance, DMI and physiological variables

\begin{tabular}{|c|c|c|c|c|c|c|c|c|}
\hline \multirow[b]{2}{*}{ Parameters } & \multicolumn{4}{|c|}{ Supplemental Cr (mg/kg DM) } & \multirow[b]{2}{*}{ SEM } & \multicolumn{3}{|c|}{ P-Value } \\
\hline & 0 & 0.5 & 1.0 & 1.5 & & Group $(\mathrm{G})$ & Period $(\mathrm{P})$ & $\mathrm{G} \times \mathrm{P}$ \\
\hline No. of buffalo calves & 6 & 6 & 6 & 6 & & & & \\
\hline Days in trial & 120 & 120 & 120 & 120 & & & & \\
\hline $\begin{array}{l}\text { Initial body mass } \\
(\mathrm{kg})\end{array}$ & 170.46 & 171.27 & 169.65 & 177.08 & 17.18 & NS & NS & NS \\
\hline $\begin{array}{l}\text { Final body mass } \\
(\mathrm{kg})\end{array}$ & 225.17 & 227.35 & 224.38 & 229.01 & 16.54 & NS & NS & NS \\
\hline Gain (kg) & 54.71 & 56.08 & 54.73 & 51.93 & 2.35 & NS & NS & NS \\
\hline $\begin{array}{l}\text { Average daily gain } \\
\text { (kg/day) }\end{array}$ & 0.455 & 0.467 & 0.456 & 0.432 & 0.08 & NS & NS & NS \\
\hline $\begin{array}{l}\text { Dry matter intake } \\
\text { (kg/100 body mass) }\end{array}$ & 2.54 & 2.50 & 2.59 & 2.53 & 0.60 & NS & NS & NS \\
\hline $\begin{array}{l}\text { Feed conversion } \\
\text { ratio }\end{array}$ & 12.02 & 11.80 & 11.91 & 12.85 & 1.00 & NS & NS & NS \\
\hline $\begin{array}{l}\text { Respiration rate } \\
\text { (breaths/min) }\end{array}$ & 16.23 & 15.82 & 16.76 & 15.75 & 0.61 & NS & NS & NS \\
\hline Pulse rate $\left(\mathrm{min}^{-1}\right)$ & 57.10 & 59.01 & 56.87 & 59.05 & 0.65 & NS & NS & NS \\
\hline $\begin{array}{l}\text { Rectal } \\
\text { temperature }\left({ }^{\circ} \mathrm{C}\right)\end{array}$ & 38.17 & 38.13 & 38.17 & 38.02 & 0.19 & NS & NS & NS \\
\hline
\end{tabular}

$\mathrm{SEM}=$ Standard error of mean, $\mathrm{G} \times \mathrm{P}=$ Interaction effect of $\mathrm{Cr}$ and winter, $\mathrm{NS}=$ Non significant $(\mathrm{P}>0.05)$.

Growth performance, nutrient digestibility and mineral bioavailability. The average values of all measurements taken for growth performance, DMI, feed conversion ratio, nutrient digestibility and $\mathrm{N}$ and trace mineral metabolism during the 120 day experimental period are depicted in Tables 2, 3 and 4. Statistical analysis revealed no distinct effect of dietary Cr supplementation on DMI, body mass gain and the efficiency of feed conversion in buffalo calves during the cold season. The interaction effect between $\mathrm{Cr}$ treatment and cold was also non-significant $(\mathrm{P}<0.05)$ for growth performance, DMI and feed conversion ratio. Digestibility of nutrients and $\mathrm{N}$ metabolism were not altered by additional dietary $\mathrm{Cr}$ supplementation. Diets with different $\mathrm{Cr}$ levels did not affect metabolism and plasma concentrations of $\mathrm{Cu}, \mathrm{Zn}$ and $\mathrm{Fe}$. However, the intake, excretion and plasma concentration of $\mathrm{Cr}$ showed a positive correlation $(\mathrm{P}<0.05)$ with supplemental $\mathrm{Cr}$ levels, and was found to be the highest in the buffalo calves fed $1.5 \mathrm{mg} \mathrm{Cr} / \mathrm{kg} \mathrm{DM}$.

Cell mediated and humoral immunity. The results concerning changes in the mitogenic response of lymphocyte, neutrophil phagocytic activity, plasma TIg, IgG concentrations and FRAP value are shown in Table 5 and Figs. 2, 3, 4 and 5. The cell mediated immune 
response of cold-stressed buffalo calves was assessed by estimation of the proliferation of $\mathrm{B}$ and T-cells and neutrophil phagocytic activity. However, the humoral immune response was determined by estimation of plasma TIg, IgG concentrations and FRAPS value. 1.5 $\mathrm{mg} \mathrm{Cr} / \mathrm{kg} \mathrm{DM}$ supplementation significantly increased $(\mathrm{P}<0.05) \mathrm{B}$ and $\mathrm{T}$ cell blastogenic response, as compared to the buffalo calves fed on a basal diet and a diet supplemented with 0.5 and $1.0 \mathrm{mg} \mathrm{Cr} / \mathrm{kg}$ DM (Fig. 2). Accordingly, increased $(\mathrm{P}<0.05)$ neutrophil phagocytic activity was observed in the buffalo calves fed the $1.5 \mathrm{mg} \mathrm{Cr} / \mathrm{kg}$ DM diet (Fig. 3). However, calves fed diets which contained 1.0 and $1.5 \mathrm{mg} \mathrm{Cr} / \mathrm{kg} \mathrm{DM}$ had higher $(\mathrm{P}<0.05)$ plasma concentrations of TIg and IgG (Fig. 4). The total antioxidant activity (FRAP value) was highest $(\mathrm{P}<0.05)$ in buffalo calves supplemented with $1.5 \mathrm{mg} \mathrm{Cr} / \mathrm{kg} \mathrm{DM}$ (Fig. 5).

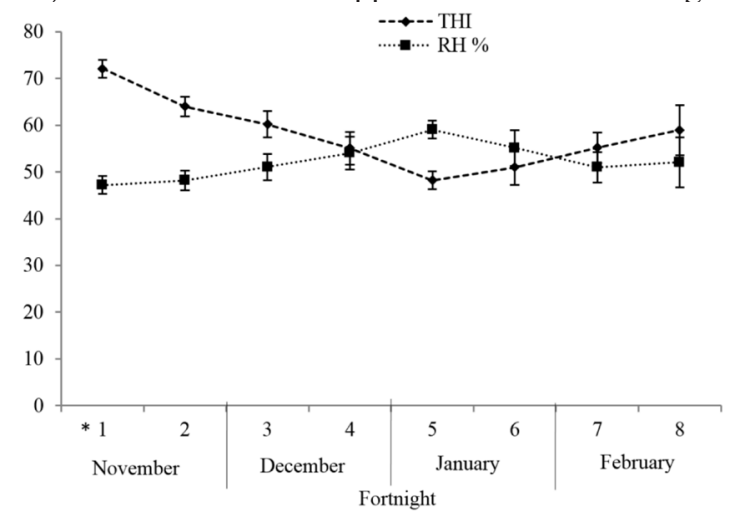

Fig. 1. Fortnightly mean values of THI and RH during the 120 day course of the experiment.

Values are the means, and vertical lines represent the $\mathrm{SE}, *=$ fortnight

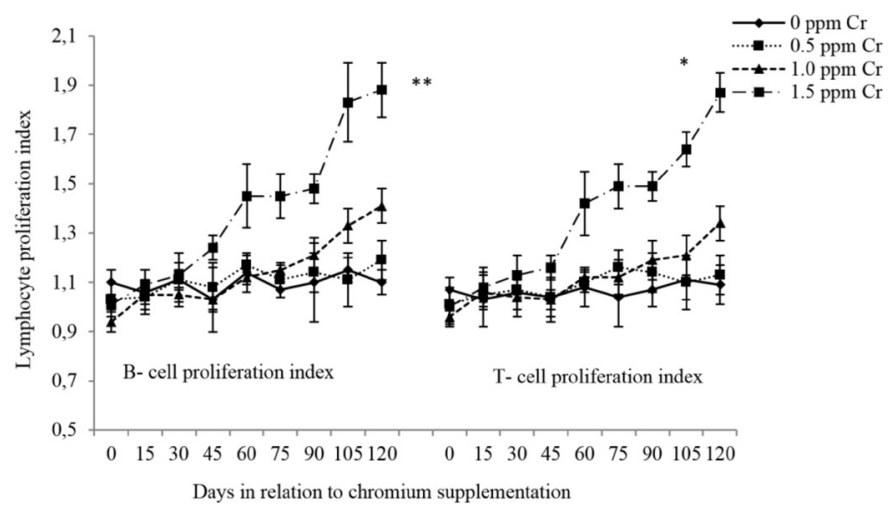

Fig. 2. The effect of chromium supplementation on lymphocyte proliferation index. Means with asterisks $(*, * *)$ differ significantly $(* \mathrm{P}<0.05$ and $* * \mathrm{P}<0.01)$. Values are the means and vertical lines represent the SE. 
M. Kumar et al.: Effect of chromium supplementation on performance of cold-stressed buffalo calves

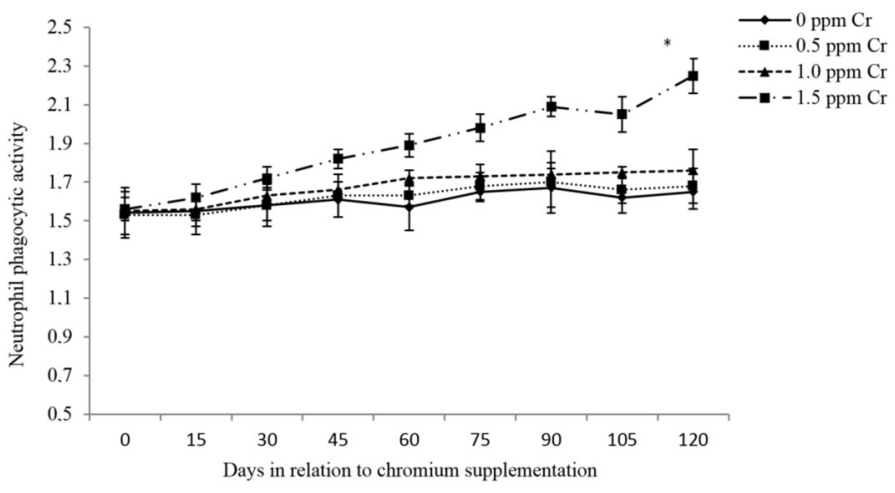

Fig. 3. The effect of chromium supplementation on neutrophil phagocytic activity. Means with an asterisk (*) differ significantly $(\mathrm{P}<0.05)$. Values are the means and vertical lines represent the SE.

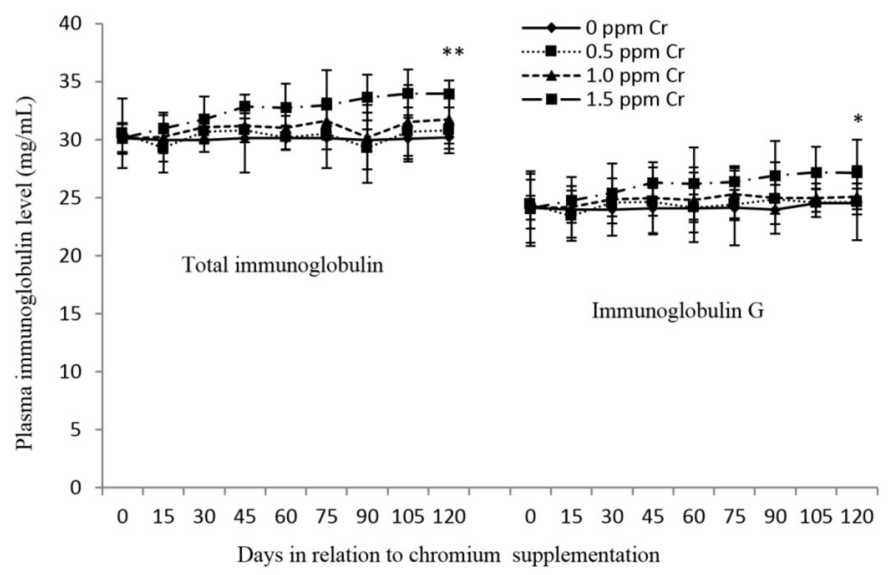

Fig. 4. The effect of chromium supplementation on immunoglobulin concentration. Means with asterisks $(*, * *)$ differ significantly $(* \mathrm{P}<0.05$ and $* * \mathrm{P}<0.01)$. Values are the means and vertical lines represent the $\mathrm{SE}$. 
M. Kumar et al.: Effect of chromium supplementation on performance of cold-stressed buffalo calves

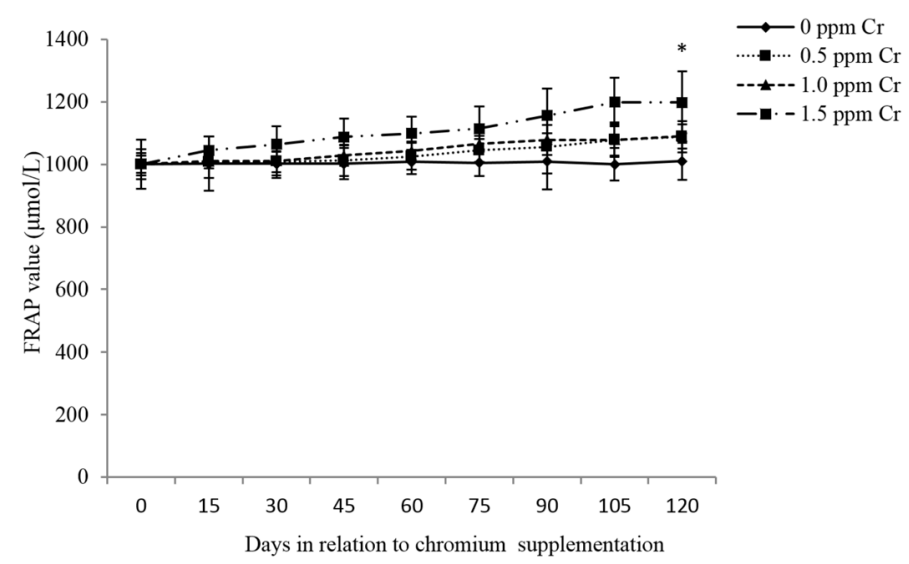

Fig. 5. The effect of chromium supplementation on ferric reducing antioxidant power value. Means with an asterisk $\left(^{*}\right)$ differ significantly $(\mathrm{P}<0.05)$. Values are the means and vertical lines represent the $\mathrm{SE}$.

\section{Discussion}

THI combines temperature and humidity in a single value and has been widely used to quantify environmental stress in dairy animals (CORREA-CALDERON et al., 2004). In the present study, THI and RH observed during the 120 day test period are considered within the normal physiological range of $35-72 \%$ (KOHLI et al., 2014). Therefore, variations in THI and RH did not exert any effect on the physiological variables, as shown by the normal RR, PR and RT in the four groups. The lack of effect of supplemental Cr on RR, PR, and RT might be attributed to the fact that the calves were not exposed to such a low ambient temperature that could alter these physiological variables. The findings of the present study on physiological variables are consistent with previous findings by KUMAR et al. (2013), who also found no effect of $\mathrm{Cr}$ supplementation on the physiological responses of heat-stressed buffalo calves. DEKA (2014) conducted a feeding trial in Murrah buffaloes to study the effect of inorganic $\mathrm{Cr}$ supplementation on immune-endocrine parameters, nutrient utilization and productive performance in similar agro climatic conditions. She found no effect of feeding diets supplemented with $0.5,1.0$ and $1.5 \mathrm{mg} \mathrm{Cr}$ as Cr-chloride/ $\mathrm{kg}$ DM on PR, RR, and RT. ANQIANG et al. (2009) also did not report any differences in $\mathrm{PR}, \mathrm{RR}$, and RT in inorganic $\mathrm{Cr}$ supplemented, transportation stressed calves.

Growth performance and mineral bioavailability. The variation in ambient temperature, THI, RH and supplemental levels of $\mathrm{Cr}$ during the cold season did not exert any effect on the DMI, growth performance and metabolism of $\mathrm{N}$ and $\mathrm{Cu}, \mathrm{Zn}$ and $\mathrm{Fe}$. Information on this aspect of how supplementation of $\mathrm{Cr}$ affects performance in buffalo 
calves during the cold season is lacking. However, in other species findings regarding the effect of $\mathrm{Cr}$ supplementation on animal performance in response to the cold season are variable. FRANK et al. (2003) reported increased feed intake and reduced feed:gain ratio in pigs housed at low temperatures compared to normal temperature. However, no effect of Cr supplementation on nutrient intake under optimum ambient temperatures was reported in periparturient Murrah buffaloes (DEKA et al., 2014) and Holstein calves (DEPEW et al., 1996). KRAIDEES et al. (2009) in transportation stressed calves, and KUMAR et al. (2015) also ascribed no effect of $\mathrm{Cr}$ supplementation on growth performance in heatstressed buffalo calves. Accordingly, no difference in average daily gain (ADG), DMI, and gain:feed ratio in calves following dietary supplementation of $1.0 \mathrm{mg} \mathrm{Cr} / \mathrm{kg}$ DM was reported by GENTRY et al. (1999). However, the beneficial effects on the performance of calves of supplemental trivalent $\mathrm{Cr}$ as $\mathrm{Cr}$-yeast, chelated-Cr or $\mathrm{Cr}$-nicotinate during a stressful period have been recorded by various workers (KRAIDEES et al., 2009). We failed to observe any beneficial effects of supplemental $\mathrm{Cr}$ in cold-stressed buffalo calves. This discrepancy may be attributed to the physiological differences between these species, and the fact that the pooled $\mathrm{Cr}$ in the body of these buffalo calves was not depleted as a result of the low ambient temperature.

Dietary Cr supplementation did not have any effect on nutrient digestibility and balance of $\mathrm{N}, \mathrm{Cu}, \mathrm{Zn}$ and $\mathrm{Fe}$. However, $\mathrm{Cr}$ balance showed a positive correlation with supplemental $\mathrm{Cr}$ levels. The results obtained in the present study are in agreement with the findings of KITCHALONG et al. (1995), who also did not report any effect of $\mathrm{Cr}$ supplementation on N balance. However, HALDAR et al. (2009) stated that supplementation of inorganic $\mathrm{Cr}$ in goats had a positive effect on $\mathrm{N}$ retention. In our research, the lack of effect of $\mathrm{Cr}$ supplementation on the metabolism of $\mathrm{Cu}, \mathrm{Zn}$ and $\mathrm{Fe}$ agrees with previously reported findings (CHANG et al., 1995). Similarly, rats fed with $\mathrm{Cr}$, at $5 \mathrm{mg} / \mathrm{kg}$ of their diet, did not show any change in plasma concentrations of $\mathrm{Cu}, \mathrm{Zn}$, and $\mathrm{Fe}$ (ANDERSON et al., 1997). In contrast to the findings of the present study, a higher dietary intake of $\mathrm{Cu}, \mathrm{Zn}$ and Fe (BISWAS et al., 2006) and a dose-dependent linear decrease in the apparent absorption of $\mathrm{Zn}$ were observed in animals fed inorganic Cr (UNDERWOOD and SUTTLE, 1999). Increased intake, excretion, and retention of $\mathrm{Cr}$ by buffalo calves fed diets supplemented with different levels of $\mathrm{Cr}$ is in agreement with the findings of SCHRAUZER et al. (1986). The apparent absorption coefficient of $\mathrm{Cr}$ from inorganic trivalent sources ranged between 4 to $10 \%$, compared to 10 to $25 \%$ for organic sources of Cr (UNDERWOOD, 1977). SPEARS (1999) also reported a dose dependent increase in tissue Cr concentrations in slaughter studies. Blood $\mathrm{Cr}$ concentration might to a certain extent reflect the intake of this element, but in cases of excessive $\mathrm{Cr}$ intake, it is inappropriate to use the blood $\mathrm{Cr}$ concentration as an indicator of Cr status in animals (UNDERWOOD, 1977). 
Cell mediated and humoral immunity. Higher cell mediated immunity was obtained with inorganic Cr supplementation in the current study, which is consistent with the findings of KUMAR et al. (2015) in heat-stressed buffalo calves. DEKA et al. (2014) showed that periparturient Murrah buffaloes supplemented with $1.5 \mathrm{mg}$ inorganic $\mathrm{Cr} / \mathrm{kg}$ DM had higher B and T-cell proliferation. CHANG et al. (1994) observed 70\% increased lymphocyte blastogenesis in response to Con $A$ in calves receiving $1.0 \mathrm{ppm}$ supplemental chelated-Cr. LIEN et al. (2005) used Escherichia coli LPS as a stress inducing agent in weanling pigs with supplementation of $0.2 \mathrm{mg} \mathrm{Cr}$-propionate $/ \mathrm{kg} \mathrm{DM}$, and found a higher lymphocyte blastogenic response. An increased blastogenic response of lymphocytes in $\mathrm{Cr}$ supplemented animals was also reported by CHANG et al. (1994). In contrast to the present study, VAN HEUGTEN and SPEARS (1997) did not ascribe any effect of supplemental $\mathrm{Cr}$ on cell mediated and humoral immune response in calves.

Increased neutrophil phagocytic activity in the buffalo calves fed a supplement of $1.5 \mathrm{mg} \mathrm{Cr} / \mathrm{kg} \mathrm{DM}$ is in accordance with the findings of DEKA et al. (2014) who also reported increased neutrophil phagocytic activity in buffaloes fed $1.5 \mathrm{mg} \mathrm{Cr} / \mathrm{kg}$ DM periparturient Murrah. A similar result was also reported by KUMAR et al. (2015), who found that the addition of inorganic $\mathrm{Cr}$ to heat-stressed buffalo calves influenced neutrophil phagocytic activity. Increased neutrophil phagocytic activity was also reported in Cr supplemented transition cattle (KAFILZADEH et al., 2012). However, no effect of dietary $\mathrm{Cr}$ supplementation on peripheral neutrophil phagocytic activity was reported by HALDAR et al. (2009).

The increase in humoral immune response in the 1.0 and $1.5 \mathrm{mg} \mathrm{Cr} / \mathrm{kg} \mathrm{DM}$ supplemented groups is consistent with the findings of KUMAR et al. (2015) and DEKA et al. (2014) who reported higher levels of TIg and IgG in Cr supplemented periparturient Murrah buffaloes and Murrah buffaloes calves, respectively. WANG et al. (2007) stated that pigs supplemented with $200 \mu \mathrm{g} / \mathrm{kg} \mathrm{Cr}$ as $\mathrm{Cr}$ - Nano had 13.2\% and 20.6\% higher serum concentrations of $\mathrm{IgM}$ and $\mathrm{IgG}$. Increased serum total $\mathrm{IgG}$ and IgM levels in high Cr-yeast supplemented calves following transport stress was also reported by MOONSIESHAGEER and MOWAT (1993). In contrast to the present study, KEGLEY et al. (1997) ascribed no change in total IgM in both high-Cr yeast and $\mathrm{Cr}$-nicotinate supplemented transport stressed calves.

In the present study, $\mathrm{Cr}$ supplementation increased FRAP values, with the group receiving $1.5 \mathrm{mg} \mathrm{Cr} / \mathrm{kg} \mathrm{DM}$ recording the highest. Information on how $\mathrm{Cr}$ supplementation alters the antioxidant status in dairy animals during cold season is not available. In a summer season study, KUMAR et al. (2015) reported increased antioxidant status in Murrah buffalo calves fed a diet supplemented with different levels of $\mathrm{Cr}$ as $\mathrm{Cr}$-chloride. PERAI et al. (2014) conducted a study on the effects of supplemental vitamin $\mathrm{C}$ and $\mathrm{Cr}$-chloride on the metabolic and hormonal responses, antioxidant status, and tonic immobility 
reactions of transported broiler chickens. They both reported that, either alone or in combination, $\mathrm{Cr}$ increased the FRAP value before transport. It has been well-established that $\mathrm{Cr}$ potentiates insulin metabolism, which alters lipid peroxidation and therefore $\mathrm{Cr}$ is postulated to function as an antioxidant (PREUSS et al., 1997). Thus, concurrent use of Cr during stress conditions enhances antioxidant capacity (SAHIN et al., 2002a). In contrary, other reports have indicated that supplemental $\mathrm{Cr}$ significantly decreased antioxidant levels (ANNE-MARIE et al., 2012).

It is not clear how the mechanism of immunomodulation and antioxidant status is induced by dietary $\mathrm{Cr}$ supplementation. The increased immune response in the present experiment might be due to the regulation of $\mathrm{Cr}$ containing specific enzymes, required for $\mathrm{B}$ and $\mathrm{T}$ cell proliferation and immunoglobulin production (FIELDEN and ROTILIO, 1984). Reduced cortisol concentration in Cr supplemented animals during stress can be correlated with improved immune response and antioxidant status (KUMAR et al., 2015). Increased cortisol concentration during stress is believed to be responsible for immunosuppression by inhibiting lymphocyte proliferation, lymphocyte activating factor and T-cell growth factor production (MUNCK et al., 1984).

\section{Conclusions}

The dietary addition of inorganic Cr in cold-stressed Murrah buffalo calves did not have any impact on physiological variables, nutrient utilization, growth performance and metabolism of $\mathrm{N}$ and $\mathrm{Cu}, \mathrm{Zn}$ and $\mathrm{Fe}$. However, the bioavailability of $\mathrm{Cr}$ showed a positive correlation with the supplemental level of $\mathrm{Cr}$. $\mathrm{Cr}$ supplementation in buffalo calves reared under low ambient temperatures increased immunity and antioxidant status, which was evident from the increased lymphocyte proliferation, neutrophil phagocytic activity, plasma immunoglobulin and total antioxidant status.

\section{References}

ANDERSON, R. A., N. A. BRYDEN, C. M. EVOCK-CLOVER, N. C. STEELE (1997): Beneficial effects of chromium on glucose and lipid variables in control and somatotropin-treated pigs are associated with increased tissue chromium and altered tissue copper, iron and zinc. J. Anim. Sci. 75, 657-666.

ANNE-MARIE, R. A. M., I. HININGER, R. M. S. BENARABA, T. N. ZIEGENFUSS, R. A. ANDERSON (2012): Antioxidant effects of a cinnamon extract in people with impaired fasting glucose that are overweight or obese. J. Am. Coll. Nutr. 28, 16-21.

ANQIANG, L., W. ZHISHENG, Z. ANGUO (2009): Effect of chromium picolinate supplementation on early lactation performance, rectal temperatures, respiration rates and plasma biochemical response of Holstein cows under heat stress. Pak. J. Nutr. 8, 940-945.

AOAC (1995): Official Methods of Analysis Association of Official Analysis Chemists. AOAC, Washington D.C. (USA). 
M. Kumar et al.: Effect of chromium supplementation on performance of cold-stressed buffalo calves

BENZIE, E. F. I., J. J. STRAIN (1999): Ferric reducing antioxidant power assay: Direct measurement of total antioxidant activity of biological fluids and modified version for simultaneous measurement of total antioxidant and ascorbic acid concentration. Methods Enzymol. 299, $15-27$.

BISWAS, P., S. HALDAR, M. C. PAKHIRA, T. K. GHOSH, C. BISWAS (2006): Efficiency of nutrient utilization and reproductive performance of pre-pubertal dairy heifers supplemented with inorganic and organic chromium compounds. J. Sci. Food. Agr. 86, 804-815.

BLAHOVÁ, J., R. DOBŠÍKOVÁ, E. STRAKOVÁ, P. SUCHÝ (2007): Effect of low environmental temperature on performance and blood system in broiler chickens (Gallus domesticus). Acta Vet. Brno. 76, 17-23.

BUnting, L. D., T. A. TARIFA, B. T. ROCHET, J. M. FERNANDEZ, C. L. DEPEW, J. C. LOVEJOY (2000): Dietary inclusion of chromium propionate and (or) calcium propionate influences gastrointestinal development and insulin function in dairy calves. J. Dairy. Sci. 83, 2491-2498.

CHAI, E. M., Y. KIM, A. KIM, J. HWANG (2005): Immunomodulating activity of arabinogalactin and fucoidan in vitro. J. Med. Food. 8, 446-455.

CHANG, X., B. A. MALLARD, D. N. MOWAT (1994): Proliferation of peripheral blood lymphocytes of feeder calves in response to chromium. Nutr. Res. 14, 851- 864.

CHANG, X., D. N. MOWAT, B. A. MALLARD (1995). Supplemental chromium and niacin for stressed feeder calves. Can. J. Anim. Sci. 75, 351-358.

CORREA-CALDERON, A., D. ARMSTRONG, D. RAY, S. DENISE, M. ENNS, C. HOWISON (2004): Thermoregulatory responses of Holstein and Brown Swiss heat-stressed dairy cows to two different cooling systems. Int. J. Biometeorol. 48, 142-148.

DEKA, R. S., V. MANI, M. KUMAR, S. S. ZADE, A. K. TYAGI (2014): Body condition, energy balance and immune status of periparturient Murrah buffaloes (Bubalus bubalis) Supplemented with Inorganic Chromium. Biol. Trace. Elem. Res. 161, 57-68.

DEPEW, C. L., L. D. BUNTING, D. L. Jr. THOMPSON, D. T. GANTT (1996): Chromium picolinate does not alter intake or lipid metabolism in lambs fed standard or high-fat diets (Abstract). J. Dairy. Sci. 79, 140.

FIELDEN, E. M., G. ROTILIO (1984): The structure and mechanism of Cu/Zn-superoxide dismutase. In: Lontie R, editor. Copper Proteins and Copper Enzymes. Boca Raton, Florida (USA). CRC, Press, pp. 7.

FRANK, J. W., J. A. CARROLL, G. L. ALLEE, M. E. ZANNELLI (2003): The effects of thermal environment and spray-dried plasma on the acute-phase response of pigs challenged with lipopolysaccharide. J. Anim. Sci. 81, 1166-1176.

GENTRY, L. R., J. M. FERNANDEZ, T. L. WARD, T. W. WHITE, L. L. SOUTHERN, D. L. THOMPSON, D. W. HOROHOV, A. M. CHAPA, T. SAHLU (1999): Dietary protein and chromium tripicolinate in Suffolk wether lambs: effects on production characteristics, metabolic and hormonal responses and immune status. J. Anim. Sci. 77, 1284-1294. 
M. Kumar et al.: Effect of chromium supplementation on performance of cold-stressed buffalo calves

HALDAR, S., S. MONDAL, S. SAMANTA, T. K. GHOSH (2009): Effects of dietary chromium supplementation on glucose tolerance and primary antibody response against peste des petits ruminants in dwarf Bengal goats (Capra hircus). Animal. 3, 209-217.

KAFILZADEH, F., H. K. SHABANKAREH, M. R. TARGHIBI (2012): Effect of chromium supplementation on productive and reproductive performances and some metabolic parameters in late gestation and early lactation of dairy cows. Biol. Trace. Elem. Res. 149, 42-49.

KEARL, L. C. (1982): Nutrient Requirement of Ruminants in Developing Countries. International Feed stuffs Institute, Utah Agricultural Experiment Station, Utah State University, Logan (USA).

KEGLEY, E. B., J. W. SPEARS, T. T. BROWN (1997): Effect of shipping and chromium supplementation on performance, immune response, and disease resistance of steers. J. Anim. Sci. 75, 1956-1964.

KITCHALONG, L., J. M. FERNANDEZ, L. D. BUNTING, L. L. SOUTHERN, T. D. BIDNER (1995): Influence of chromium tripicolinate on glucose metabolism and nutrient partitioning in growing lambs. J. Anim. Sci. 73, 2694-2704.

KOHLI, S., U. K. ATHEYA, A. THAPLIYAL (2014): Assessment of optimum thermal humidity index for crossbred dairy cows in Dehradun district, Uttarakhand, India. Vet. World. 7, 916921.

KRAIDEES, M. S., I. A. AL-HAIDARY, S. I. MUFARREJ, M. Y. AL-SAIADY, H. M. METWALL, M. F. HUSSEIN (2009): Effect of supplemental chromium levels on performance, digestibility and carcass characteristics of transport-stressed lambs. Asian Austral. J. Anim. Sci. 22, 11241132.

KUMAR, M., H. KAUR, A. TYAGI, V. MANI, R. S. DEKA, G. CHANDRA, V. K. SHARMA (2013): Assessment of chromium content of feedstuffs, their estimated requirement, and effects of dietary chromium supplementation on nutrient utilization, growth performance, and mineral balance in summer-exposed buffalo calves (Bubalus bubalis). Biol. Trace. Elem. Res. 155, 29-37.

KUMAR, M., H. KAUR, R. S. DEKA, V. MANI, A. K. TYAGI, G. CHANDRA (2015): Dietary inorganic chromium in summer-exposed buffalo calves (Bubalus bubalis): effects on biomarkers of heat stress, immune status, and endocrine variables. Biol. Trace. Elem. Res. $167,18-27$.

LIEN, T. F., K. H. YANG, K. J. LINK (2005): Effects of chromium propionate supplementation on growth performance, serum traits and immune response in weaned pigs. Asian Austral. J. Anim. Sci. 18, 403-408.

MARAI, I. F. M., A. A. M. HAEEB (2010): Buffalo's biological functions as affected by heat stress - A review. Livest. Sci. 127, 89-109.

MATSUMOTO, M., H. J. HUANG (2000): Induction of short-term, nonspecific immunity against Escherichia coli infection in chickens is suppressed by cold stress or corticosterone treatment. Avian Pathol. 29, 227-232. 
M. Kumar et al.: Effect of chromium supplementation on performance of cold-stressed buffalo calves

McDOWELL, R. E., N. W. HOOVEN, J. K. CAMOENS (1976): Effect of climate on performance of Holsteins in first lactation. J. Dairy. Sci. 59, 965-973.

McEVAN, A. D., E.W. FISHER (1970): A turbidity test for the estimation of immunoglobulins levels in neonatal calf serum. Clin. Chim. Acta. 27, 155-163.

MOONSIE-SHAGEER, S., D. N. MOWAT (1993): Effect of level of supplemental chromium on performance, serum constituents, and immune status of stressed feeder calves. J. Anim. Sci. 71, 232-238.

MOSMANN, T. (1983): Rapid colorimetric assay for cellular growth and survival application to proliferation and cytotoxicity assay. J. Immunol. Methods. 65, 55-63.

MUNCK, A., P. GUYRE, N. HOLBROOK (1984): Physiological functions of glucocorticoids in stress and their relation to pharmacological actions. Endocr. Rev. 5, 25-44.

NRC (1997): The Role of Chromium in Animal Nutrition. National Research Council, National Academy Press, Washington D.C. (USA).

PERAI, H., H. KERMANSHAHI, H. NASSIRI MOGHADDAM, A. ZARBAN (2014): Effects of supplemental vitamin $\mathrm{C}$ and chromium on metabolic and hormonal responses, antioxidant status, and tonic immobility reactions of transported broiler chickens. Biol. Trace. Elem. Res. 157, 224-233.

PREUSS, H. G., P. L. GROJEC, S. LIEBERMAN, R. A. ANDERSON (1997): Effects of different chromium compounds on blood pressure and lipid peroxidation in spontaneously hypertensive rats. Clin. Nephrol. 47, 325-330.

SAHIN, K., N. SAHIN, O. KUCUK (2002a): Effects of dietary chromium and ascorbic acid supplementation on digestion of nutrients, serum antioxidant status, and mineral concentrations in laying hens reared at a low ambient temperature. Biol. Trace. Elem. Res. 87, 113-124.

SAHIN, K., O. OZBEY, M. ONDERCI, G. CIKIM, M. H. AYSONDU (2002b): Chromium supplementation can alleviate negative effects of heat stress on egg production, egg quality and some serum metabolites of laying Japanese quail. J. Nutr. 132, 1265-1268.

SAHIN, N., K. SAHIN, M. ONDERCI, M. F. GURSU, G. CIKIM, J. VIJAYA, O. KUCUK (2005). Chromium picolinate, rather than biotin, alleviates performance and metabolic parameters in heat-stressed quail. Brit. Poultry. Sci. 464, 57-463.

SCHRAUZER, G. N., K. P. SHRESTHA, T. B. MOLENAAR, S. MEADE (1986): Effects of chromium supplementation on food energy utilization and the trace element composition in the liver and heart of glucose-exposed young mice. Biol. Trace. Elem. Res. 9, 79-86.

SINGH, R., D. N. SINGH, R. S. YADAV (2014): Growth performance and feed intake of buffalo heifers under different housing system during winter season. Int. J. Sci. Environ. Technol. 3, 314-319.

SPEARS, J. W. (1999): Reevaluation of the metabolic essentiality of the minerals: review. Asian Austral. J. Anim. Sci. 12, 1002-1008.

UNDERWOOD, E. J. (1977): Chromium, in trace elements in human and animal nutrition, $4^{\text {th }}$ edn. Academic Press, New York (USA). pp. 258-270. 
M. Kumar et al.: Effect of chromium supplementation on performance of cold-stressed buffalo calves

UNDERWOOD, E. J., N. F. SUTTLE (1999): The Mineral Nutrition of Livestock, $3^{\text {rd }}$ edn. CABI Publishing, London (United Kingdom). pp. 517-522.

Van HEUGTEN, E., J. W. SPEARS (1997): Immune response and growth of stressed weanling pigs fed diets supplemented with organic or inorganic forms of chromium. J. Anim. Sci. 75, 409-416.

Van SOEST, P. J., J. B. ROBERTSON, B. A. LEWIS (1991): Methods for dietary fiber, neutral detergent fiber, and non starch polysaccharides in relation to animal nutrition. J. Dairy. Sci. 74, 358-397.

WANG, M. Q., Z. R. XUA, L. Y. ZHA, M. D. LINDEMANN (2007): Effects of chromium nanocomposite supplementation on blood metabolites, endocrine parameters and immune traits in finishing pigs. Anim. Feed. Sci. Tech. 139, 69-80.

WEISS, W. P., J. W. SPEARS (2005): Vitamin and trace mineral effects on immune function of ruminants. $10^{\text {th }}$ International Symposium on Ruminant Physiology, Wageningen (Netherlands).

Received: 30 January 2016

Accepted: 24 October 2016

KUMAR, M., H. KAUR, V. MANI, R. S. DEKA, A. K. TYAGI, G. CHANDRA, A. K. DANG, R. KUSHWAHA: Dodatak kroma u teladi azijskog vodenog bivola (Bubalus bubalis) pod stresom od hladnoće: učinci na prirast, hranidbenu iskoristivost te staničnu i humoralnu imunost. Vet. arhiv 87, 441-456, 2017.

\section{SAŽETAK}

Različiti stresori značajno povećavaju izlučivanje kroma $(\mathrm{Cr})$ mokraćom što naznačuje da $\mathrm{Cr}$ može biti fiziološki vezan s odgovorom za kontrolu stresa. Cilj je ovog rada bio odrediti fiziološke odgovore u bivolje teladi na povećani dodatak $\mathrm{Cr}$ u uvjetima niske temperature okoliša. Prema metodi slučajnog odabira skupina, 24 Murrah bivolska teleta bila su raspodijeljena u četiri skupine koje su bile različito tretirane u razdoblju od 120 dana. Životinjama jedne skupine dodavano je $0,5 \mathrm{mg} \mathrm{Cr} / \mathrm{kg}$ suhe tvari, druge skupine $1,0 \mathrm{mg} \mathrm{Cr} / \mathrm{kg}$ suhe tvari, a treće skupine $1,5 \mathrm{mg} \mathrm{Cr} / \mathrm{kg}$ suhe tvari, dok kontrolnoj skupini $\mathrm{Cr}$ nije bio dodavan. $\mathrm{U}$ teladi su dnevno bile promatrane fiziološke varijable, uzimanje suhe tvari te svaka dva tjedna promjena tjelesne mase. Uzorci krvi bili su uzimani u razmacima od 14 dana i pretraženi na biomarkere imunosti i koncentraciju minerala u tragovima u plazmi. Na kraju pokusnog razdoblja od 120 dana proveden je sedmodnevni metabolički pokus. Prosječni indeks temperature i vlažnosti tijekom istraživanja iznosio je 58,10 jedinica dok je relativna vlažnost bila 52,0 \%. Fiziološke varijable, uzimanje suhe tvari i prirast reducirajućeg željeza nisu se razlikovali među skupinama. Količina od $1,5 \mathrm{mg} \mathrm{Cr} / \mathrm{kg}$ suhe tvari povećala je proliferaciju B- i T-limfocita, fagocitoznu aktivnost neutrofila i vrijednost antioksidacijske sposobnosti, dok su koncentracije ukupnih imunoglobulina plazme i imunoglobulina $\mathrm{G}(\mathrm{IgG})$ bile najveće u skupinama koje su dobivale 1,0 odnosno $1,5 \mathrm{mg} \mathrm{Cr} / \mathrm{kg}$ suhe tvari. Nutritivna probavljivost, metabolizam dušika $(\mathrm{N})$ i biološka raspoloživost minerala u tragovima nisu se razlikovali među skupinama. Biološka raspoloživost Cr bila je u korelaciji s razinom njegova dodatka. Rezultati upućuju na zaključak da povećani dodatak $\mathrm{Cr}$ u hladnoći može poboljšati imunosni odgovor bez utjecaja na fiziološki odgovor, prirast i hranidbenu iskoristivost u bivolje teladi.

Ključne riječi: bivol, telad, krom, prirast, imunost, stres, hladnoća 